\title{
Razão, Emoção e Ação em Cena: A Mente Humana sob um Olhar Evolucionista
}

\author{
Angela Donato Oliva ${ }^{1}$ \\ Universidade Federal do Rio de Janeiro \\ Emma Otta \\ Fernando Leite Ribeiro \\ Vera Silvia Raad Bussab \\ Universidade de São Paulo \\ Fívia de Araujo Lopes \\ Maria Emilia Yamamoto \\ Universidade Federal do Rio Grande do Norte \\ Maria Lucia Seidl de Moura \\ Universidade do Estado do Rio de Janeiro
}

\begin{abstract}
RESUMO - O conhecimento científico da mente humana tem avançado desde a fundação da Psicologia. Aspectos biológicos e culturais, psicológicos e neurológicos, emocionais e racionais foram privilegiados separadamente em diferentes épocas e perspectivas - a visão de mente foi por vezes focalizada e por vezes relegada à caixa preta da ciência psicológica. Contemporaneamente, assiste-se a buscas de integração entre mente e comportamento humanos. A mente é vista como objeto da ciência e produto da seleção natural na evolução da espécie do Homo sapiens sapiens. Este trabalho visa apresentar uma breve história das principais transformações na concepção da mente, e de modelos evolucionistas de mente que contemplem a razão, a emoção e as ações humanas. Busca-se integrar e discutir as evidências das pesquisas de diversas disciplinas (Antropologia, Etologia, Primatologia, Psicologia, etc) oferecendo uma compreensão evolucionista da mente humana, de sua filogênese e ontogênese. Comportamentos cooperativos e competitivos serão discutidos a partir dessas perspectivas.
\end{abstract}

Palavras-chave: psicologia evolucionista; cognição; emoção; ação.

\section{Reason, Emotion and Action in Scene: Human Mind from an Evolutionary Perspective}

\begin{abstract}
Biological and cultural aspects, psychological and neurological aspects, emotional and rational aspects were privileged separately in different times and perspectives - the vision of mind was sometimes focused and sometimes relegated to the black box of the psychological science. Presently, integration between mind and human behavior is sought. Mind is seen as an object of science and a product of the natural selection in the evolution of Homo sapiens. Our essay presents a brief history of the main transformations in the conception of mind and of evolutionary models of mind which contemplate reason, emotion and human actions. An effort is made to integrate and discuss the research evidence from various disciplines (anthropology, ethology, primatology, and psychology), offering an evolutionary comprehension of the human mind, of its phylogeny and ontogeny. Cooperative and competitive behavior are discussed within such framework.
\end{abstract}

Key words: evolutionary psychology; cognition; emotion; action.

\section{Estudar a mente: especulação ou possibilidade?}

A mente humana tem atraído a atenção de diversos pesquisadores na atualidade, mas a história da Psicologia mostra que nem sempre foi assim. A tentativa de W. Wundt de entender como a mente funciona sofreu críticas contundentes. Ele realizou experimentos, ao invés de especular filosoficamente sobre a mente, com o objetivo (para a Psicologia dos processos elementares) de investigar a experiência sensorial consciente, buscando fragmentá-la até seu elemento essencial e irredutível. O método que considerou viável cientificamente para executar essa tarefa foi o da introspecção.

1 Endereço: Rua Caçapava 59, ap. 201, Grajaú, Rio de Janeiro, RJ, Brasil 20541-350.E-mail: angeladonatoliva@uol.com.br
As reações à Psicologia de Wundt voltaram-se tanto ao método quanto ao objeto de estudo. Um dos resultados dessas reações foi o surgimento da perspectiva behaviorista, que passou a considerar não científico o estudo da mente, e elegeu como objeto da Psicologia o comportamento humano observável. Essa perspectiva, em suas diversas versões (E-R, E-O-R, behaviorismo radical, etc), dominou o cenário da Psicologia americana ou anglo-saxã até o final da década de 1940. A partir de então, foram surgindo críticas que mostravam limitações do behaviorismo na explicação do comportamento. Contudo, fazer frente à imposição behaviorista de não estudar estados mentais colocava um desafio para os teóricos: abrir a caixa preta de maneira objetiva para estudar o seu conteúdo, os processos mentais da cognição humana, utilizando métodos que levassem a resultados confiáveis, sem 
distorções ou interferências subjetivas. É claro que essa tarefa - substituir o estudo do comportamento pelo estudo da mente - não se mostraria nada fácil nos anos de 1950.

O conjunto de iniciativas de abertura da caixa preta tem sido denominado de movimento (ou revolução) cognitivista e algumas tendências o caracterizam, entre elas a concepção de um sujeito ativo do conhecimento, a valorização das noções de regra, estratégias, inferências, planos e a retomada do conceito de consciência, considerada como biológica e social (Penna, 1986).

Na década de 1950, organizam-se iniciativas multidisciplinares e surge uma nova ciência (ou ciências) da cognição, com a convergência de diversas áreas, como a Psicologia cognitiva, as ciências da computação e a lingüística. O projeto de ciências da cognição não é um projeto unitário, nem do ponto de vista das disciplinas que o compõem nem do referencial teórico que adotam. De comum, pode-se apontar a busca da elaboração de uma teoria sobre a cognição ou, mais especificamente, uma teoria sobre os sistemas inteligentes.

Modelos da cognição passam a especificar seus componentes fundamentais como sendo um sistema de processamento de informação que inclui uma unidade de memória capaz de estocar tanto o programa como os dados, componentes responsáveis pela entrada e saída de informações e um processador com capacidade para manipular e transformar símbolos. Independentemente das divergências sobre o tipo de processamento (serial ou paralelo), a cognição humana é tratada pelos modelos computacionais sem considerações sobre seus aspectos funcionais e, nesse sentido, sua história evolutiva é ignorada, ou negligenciada (Seidl de Moura, 2005).

\section{Modularidade e fluidez cognitiva: a filogênese e a ontogênese}

Princípios e idéias da teoria da evolução das espécies, até recentemente, não afetaram de forma significativa a Psicologia, apesar de terem sua importância reconhecida. Só a partir dos anos de 1990 (Rodrigues \& Otta, 2002), principalmente, as bases biológicas do comportamento humano passam a ser alvo de renovado interesse. Uma das consequiências dessa tendência foi o surgimento da Psicologia evolucionista, que se baseia nos pressupostos da teoria da evolução das espécies de Charles Darwin, e desenvolvimentos posteriores (neodarwinismo). Barkow, Cosmides e Tooby (1992), pioneiros dessa abordagem, consideram a existência de uma natureza humana universal constituída de mecanismos psicológicos, produtos da evolução. Esses mecanismos são adaptações resultantes de um processo de seleção natural ao longo do tempo evolutivo, (o modo de vida de nossos ancestrais caçadores-coletores). É também nítida a influência que esses autores receberam da concepção modular proposta por Fodor (1983) sobre a mente humana.

Pode-se, então, considerar a Psicologia evolucionista como o casamento da biologia da evolução com a Psicologia cognitiva contemporânea. A arquitetura mental hipotetizada é considerada resultante da seleção natural, a metáfora é computacional e a imagem que dela se faz é a de um processador de informações (Cosmides \& Tooby, 1999).

O processador de informações segundo a Psicologia evolucionista, na perspectiva de Barkow e cols. (1992), não é um solucionador geral de problemas. O modelo modular é adotado, considerando a história da espécie. O processador central, um dos níveis propostos por Fodor, mas inaccessível para ele, é deixado de lado, e é assumida uma perspectiva de alta especialização. Esta especialização, de modularização maciça, é representada pela imagem de um canivete suíço (Evans \& Zarate, 1999), que tem diversas lâminas, uma para cada finalidade.

Na adoção apenas do nível de módulos, são abandonados pelos evolucionistas aspectos que, para Fodor, são os mais instigantes da mente: seu holismo, "sua paixão pelo analógico" e seu não-encapsulamento. Supondo que não existiriam problemas gerais a serem resolvidos, não é visto lugar para um processador geral. Os problemas enfrentados por nossos ancestrais seriam específicos: detectar predadores, discriminar falsos alarmes, selecionar o alimento adequado, formar alianças sociais, selecionar parceiros, etc.

Os módulos propostos não fornecem apenas uma sintaxe ou algoritmos genéricos. São, sim, "ricos em conteúdo", oferecendo a informação específica que é necessária para cada problema a ser solucionado (Mithen, 1996/1998). Barkow e cols. (1992) usam, como Chomsky e Fodor, o argumento básico da pobreza do estímulo para defender esses módulos muito especificados. Segundo eles, não seria possível a aprendizagem de tantos comportamentos complexos por um membro da espécie ao longo do curso da vida, não fossem os módulos. Por essa razão, os autores evolucionistas propõem um grande número deles, entre os quais os de: reconhecimento de faces, uso de ferramentas, relações espaciais, medo, cuidados de crianças, inferências sociais, aquisição da gramática, comunicação e pragmática e teoria da mente - alguns mais consensuais e outros mais controversos.

Esta modularização maciça, sem processamento central é um dos possíveis problemas da concepção de arquitetura da mente da Psicologia evolucionista. Rode e Wang (2000) consideram que, além da variedade de definições possíveis do termo módulos, se um modelo estritamente de domínios específicos for pressuposto, fica a questão de como os problemas atuais, com os quais nossos ancestrais não se deparavam, são resolvidos. Um outro problema é o de que não há lugar para a flexibilidade ou para a fluidez cognitiva. Se o funcionamento da mente humana é altamente especializado e produto de módulos selecionados por seu papel na solução de problemas característicos do ambiente evolutivo original, como explicar a capacidade metaprocessual do Homo sapiens sapiens? Por que nascemos com um cérebro ainda por desenvolver-se? Uma visão evolucionista, amparada em evidências de registros fósseis, pode ajudar a superar esse dilema.

Apesar das divergências, a idéia de alguma especificidade de processamento em domínios, como os da linguagem ou de certos padrões visuais que se assemelham a faces, é atualmente quase consensual. Em meio a esse acordo geral, há autores que defendem a modularidade sem processamento central (Barkow \& cols., 1992); há os que defendem a substituição da hipótese de módulos pela de domínios, mais flexível (Karmiloff-Smith, 1995); há os que supõem a presença e a função adaptativa de um processador central na mente do Homo sapiens sapiens. Mithen (1996/1998), um arqueólogo que apresenta consistente argumentação nesse sentido, é um desses autores. Segundo ele, a evolução da 
mente de nossa espécie caminhou tanto na direção de um aumento da fluidez cognitiva e desenvolvimento de formas generalizadas de pensamento, como de progressiva especialização ou modularização.

Para Mithen (1996/1998), com uma visão oposta à de Barkow e cols. (1992), foi justamente a mudança de uma mentalidade especializada para generalizada que caracterizou o passo fundamental para a mente moderna. A capacidade de processamento central foi o que possibilitou aos membros da espécie desenvolver instrumentos complexos, criar arte e desenvolver ideologias religiosas em que acreditar. Todas essas conquistas dependem da fluidez cognitiva. Deste modo, o aumento da fluidez cognitiva e da capacidade de processamento central possibilita a realização de novos tipos de atividade caracteristicamente humanos. Novos produtos têm origem nessas atividades e ensejam a disponibilidade de novos contextos de desenvolvimento para os membros da espécie.

Em vez do canivete suíço, a metáfora escolhida por Mithen para pensar o modelo da arquitetura da mente do Homo sapiens sapiens é a da catedral, com uma nave central comunicando-se com diversas capelas laterais adjacentes. Milhões de anos de evolução, que podem ser sintetizados em três grandes fases, deram origem a essa arquitetura (Mithen, 1996/1998).

Na fase 1, as mentes do ancestral comum aos humanos, símios, macacos e lêmures, que viveu em período anterior a 55 milhões de anos atrás, eram regidas por um domínio de inteligência geral, que envolve um conjunto de regras sobre aprendizagem geral e tomada de decisão.

Mudanças importantes ocorrem na fase 2. Ela é caracterizada por um tipo de mente na qual várias inteligências especializadas funcionariam independentemente, tratariam de domínios específicos e suplementariam a inteligência geral. O primeiro desses domínios é o da inteligência social, que aparece em período posterior a 55 milhões de anos atrás, e que se complexifica entre 35 e seis milhões de anos atrás. Em seguida surgem na mente dos primeiros Homo, os Homo habilis, entre quatro e 1,8 milhões anos atrás, os módulos da inteligência técnica e da inteligência naturalística. Essa especialização inicial torna-se mais complexa entre $1,8 \mathrm{mi}$ lhões e 100 mil anos atrás na mente dos humanos arcaicos. A inteligência técnica aumenta, assim como a complexidade da inteligência naturalística, permitindo a construção de mapas mentais do ambiente, e da inteligência social. Um novo domínio é acrescentado, o da linguagem. Assim, temse a especialização e inteligência geral, mas uma limitação ainda existe. Essa limitação é a falta de comunicação entre esses diferentes domínios (capelas na metáfora) e com a inteligência geral (nave central).

Na fase 3, essa limitação é superada. Esse é o último passo na evolução, marcado pela presença de uma mente na qual as múltiplas inteligências especializadas podem trabalhar juntas sob a coordenação de uma inteligência geral, havendo comunicação entre elas. Essa é a mente do Homo sapiens sapiens, especialmente na transição do período Paleolítico Médio para o Superior.

Pensar a arquitetura da mente contemporânea, portanto, pressupõe levar em conta algumas das características da espécie e de sua evolução. Isso não basta, entretanto, e há que considerar a importância da ontogênese. Alguns evolucionistas, como Barkow e cols.(1992), não parecem atribuir um lugar particularmente interessante para a ontogênese. Consideram que as adaptações psicológicas podem estar programadas para aparecer, desaparecer ou se modificar em momentos diferentes do desenvolvimento, para se imbricar com as demandas específicas das tarefas de cada etapa, mas focalizam, principalmente, o comportamento e funcionamento mental adulto, não pressupondo nenhum processo de construção ou de desenvolvimento ontogenético. No entanto, é possível ter uma concepção evolucionista da mente, atribuindo um papel à ontogênese, como propõe Keller (2000).

Karmiloff-Smith $(1995,2000)$, baseando-se no conhecimento sobre a plasticidade do desenvolvimento inicial do cérebro, apresenta um modelo de processo de modularização e gradual aumento de disponibilidade de representações. Para ela, a mente só se torna modular com o desenvolvimento. $\mathrm{O}$ ponto de partida desse processo de modularização é um conjunto limitado de predisposições inatas de natureza domínio-específica, que impõe limites quanto aos tipos de input que a mente processa.

As predisposições inatas são epigenéticas e envolvem domínios e não módulos, para Karmiloff-Smith. Os módulos ou sistemas de input, para Fodor, são geneticamente especificados, com finalidades especiais, funcionam independentemente, focalizando inputs selecionados, e não são sensíveis a metas cognitivas centrais. Com isso, seu funcionamento é automático e veloz. Em contraste, os domínios consistem em um conjunto de representações que apóia uma área específica de conhecimento como de linguagem, número, física, etc.

Karmiloff-Smith não pressupõe, em seu modelo, mudanças gerais simultâneas ocorrendo em vários domínios. Não há, assim, estágios gerais. As predisposições inatas, produto da filogênese, não restringem, mas, sim, potencializam o desenvolvimento. Permitem que, inicialmente, o bebê humano aceite como input apenas dados que é capaz de computar de forma específica, limitando, assim, a gama de hipóteses a serem consideradas. A partir desses limites impostos por predisposições inatas, tanto específicas como não-específicas, o desenvolvimento dá-se por um processo, esse sim, geral, que a autora denomina redescrição representacional.

A mente do bebê incluiria predisposições ou redes para o processamento de informações ou tipos diferentes de input (ex. faces), ou especificações de arquitetura, mas sem conteúdo representacional. As representações emergiriam das interações entre esses limites de arquitetura e a estrutura de tipos diferentes de input (em relação a faces, a aprendizagem das características de diferentes tipos de faces). O modelo pressupõe que as redes aprendem (modificam-se) ao assimilar o input que é processado e ao incorporar as mudanças representacionais decorrentes da estrutura do input. Essa aprendizagem dá-se lentamente. A representação emerge das atividades da rede e pode ser armazenada.

O conhecimento armazenado na mente toma, segundo ela, duas direções. Uma, no sentido de tornar-se cada vez mais encapsulado, mais automático e menos acessível, por um processo gradual de procedimentalização; outra, de tornar-se cada vez mais acessível. Observam-se, assim, os dois movimentos propostos por Mithen (1996/1998) em relação à filogênese: gradual modularização e aumento da fluidez cognitiva. 
Estas propostas, no entanto, ainda dão pouco destaque ao aspecto emocional da mente humana. A cognição saiu da caixa preta, e a ela se atribui uma história filogenética, mas essa história não pode ser completa sem que seja tratado o papel das emoções, o que só recentemente começa a ser feito, como será visto no próximo tópico.

\section{Entra em cena a emoção}

Não há fenômeno psicológico mais relevante para o homem comum do que as emoções, seja na vida normal, seja nos estados patológicos. Darwin (1872/1965) dedicou um de seus livros ao estudo das emoções nos animais e homens. Elas foram examinadas na filosofia grega, e filósofos mais recentes, como Espinoza e Descartes, escreveram extensamente sobre o assunto; na literatura de ficção, assim como nos mitos, as emoções humanas desempenham papel central.

É no patrimônio cultural, e não na introspecção, que escritores e filósofos colhem sua matéria prima. A linguagem cotidiana do homem comum tem um conjunto de palavras que designam variações ou tipos de emoções. A cultura não apenas fornece os nomes de um conjunto de emoções. Oferece-nos também um discurso sobre suas causas e consequiências. Teria sido muito natural, portanto, que a construção da Psicologia tivesse priorizado as emoções entre todos os seus assuntos, mas não foi isso que se verificou ao longo do século XX. Justifica-se o espanto de Antonio Damásio (2000), expresso em seu livro Em busca de Espinoza, diante da precariedade do estudo científico das emoções.

\section{Emoção como o "Fantasma na Máquina"}

Na primeira metade do século xx, na busca de objetividade e status científico, com a adoção, um tanto ingênua, pela Psicologia de modelos inspirados nas ciências físicas, as emoções e todos os seus parentes - as coisas que são sentidas - foram lançadas à margem da hierarquia de interesses ou inteiramente desqualificadas. Os estados mentais e subjetivos, chamados pelos psicólogos behavioristas "fantasmas da máquina", não constituíam temas adequados de estudo.

A partir de meados do século passado, esse quadro começou a mudar, o que pode ser ilustrado pela revisão feita na base de dados Web of Science, que indica uma retomada progressiva no interesse da Psicologia pelo estudo das emoções no período de 1955 a 2004 (Tabela 1).

No mesmo período, pode-se verificar uma tendência a aumento de registros dos conceitos de cognição e emoção, em termos relativos, conforme representado na Figura 1.

Tabela 1. Número de títulos de artigos contendo os termos emoção, cognição e aprendizagem, de 1955 a 2004, de acordo com os critérios da base de dados Web of Science.

\begin{tabular}{ccccc}
\hline Período & Emoção & Cognição & Aprendizagem & Total \\
\hline $1955-1964$ & 135 & 73 & 3836 & 4044 \\
$1965-1974$ & 246 & 249 & 10023 & 10518 \\
$1975-1984$ & 558 & 1203 & 13965 & 15726 \\
$1985-1994$ & 2260 & 4081 & 27797 & 34138 \\
$1995-2004$ & 9695 & 15622 & 86461 & 111778 \\
\hline
\end{tabular}

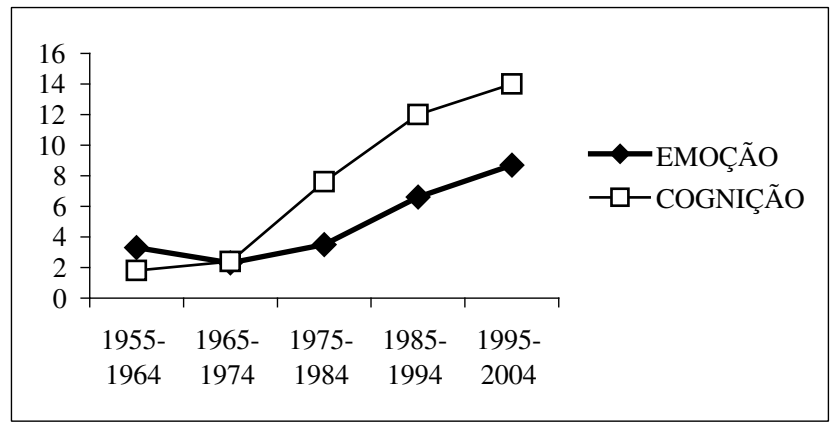

Figura 1. Participações relativas dos termos cognição e emoção em títulos de artigos publicados de 1955 a 2004, de acordo com os critérios da base de dados da Web of Science. O percentil correspondente à aprendizagem, que completaria a soma para $100 \%$, não foi incluído no gráfico.

O estudo da mente como um mecanismo de máquinas de processamento de informações foi reabilitado pela revolução cognitiva (LeDoux, 1994, 1996, 2002), na segunda metade do século XX. No entanto, assim como o behaviorismo, a revolução cognitiva também excluiu a emoção como um tópico de pesquisa. Podemos dizer que a ciência cognitiva retomou o conceito grego de mente como razão e lógica. Desde os gregos, os pensadores têm uma tendência para separar cognição e emoção, dois aspectos contrastantes em luta pelo controle do psiquismo humano.

Em vista desta tradição de separar emoção e razão, somando-se a idéia de manter a objetividade para estudar a caixa preta, compreende-se a estratégia adotada por cientistas cognitivos da envergadura de Gardner (1985): estudar a racionalidade independentemente das emoções:

\begin{abstract}
"há a decisão deliberada de diminuir a ênfase de certos fatores que podem ser importantes para o funcionamento cognitivo, mas cuja inclusão nesse momento complicaria de forma desnecessária o empreendimento científico-cognitivo. Esses fatores incluem a influência de fatores afetivos ou emoções..." (Gardner, 1985, p. 6).
\end{abstract}

\section{Reabilitação das emoções pela Psicologia evolucionista}

A Psicologia evolucionista transformou o estudo das emoções de figurante em protagonista. Cosmides e Tooby (2000) não identificam cognição com pensamento, mas consideram cognição tudo o que é mental. Não falam em efeitos das emoções sobre a cognição, porque para eles cognição refere-se a todas as operações do cérebro, incluindo emoções e raciocínio e não a um subconjunto de operações. Nessa visão abrangente da mente, emoção e cognição são faces da mesma moeda e não moedas diferentes, posição também adotada por LeDoux (1994, 1996, 2002).

A moderna Psicologia evolucionista põe as emoções em foco, entendendo-as como programas super-ordenados que coordenam muitos outros, ou seja, como soluções de problemas adaptativos de mecanismos de orquestração: organizam percepções, atenção, inferência, aprendizagem, memória, escolha de objetivos, prioridades motivacionais, estruturas conceituais, categorizações, reações fisiológicas, reflexos, decisões comportamentais, processos de comunicação, níveis de energia e de alocação de esforços, coloração afetiva de eventos e de estímulos, avaliações da situação, valores, 
variáveis reguladoras, como auto-estima, e assim por diante. Cada emoção atua sobre vários outros programas adaptativos, desativando alguns, ativando outros e mudando os parâmetros de terceiros, permitindo que todo o sistema opere de modo eficaz e harmonioso, toda vez que se defrontar com certos tipos de condições. Numa situação típica de medo, por exemplo, ativa-se o circuito de detecção da presença de algo ameaçador. Ocorrem mudanças na percepção e na atenção, exemplificáveis pela redução do limiar para pequenos ruídos. Há mais detecção de perigos à custa do aumento de alarmes falsos. A mudança motivacional é notável; a segurança ganha prioridade máxima. Não se tem mais fome, não se pensa mais em conquistar um namorado, ou em treinar nova habilidade. Há um redirecionamento de objetivos: Onde está meu bebê? Onde estão meus pais? Meus amigos? Onde estão os que podem me proteger? Ganham prioridade determinadas categorias, como perigoso ou seguro. As reações fisiológicas parecem depender da natureza exata da ameaça e da melhor maneira de enfrentá-la.

Convém notar que as emoções não são necessariamente conscientes. $\mathrm{O}$ cérebro foi projetado pela evolução para usar informações derivadas do ambiente e do próprio organismo a fim de regular funcionalmente o comportamento e o próprio corpo, e isto reúne aspectos cognitivos e emocionais. Como reunir aprendizagem com amor, ciúme e nojo? O termo cognição é às vezes usado para se referir a um tipo de pensamento deliberado, voltado para uma solução de problema, como na matemática ou no jogo de xadrez, um pensamento "frio", isento de paixão. Na perspectiva evolucionista, o conceito de cognição tem de servir para todas as atividades cognitivas, "quentes" ou "frias", e não para algum subconjunto de operações. Esta visão da perspectiva evolucionista abre novas possibilidades de investigação obscurecidas por outros esquemas.

As emoções nessa perspectiva podem ser compreendidas como forças impulsionadoras, moldadas pela seleção natural, que nos motivam à ação, levando-nos a fazer uso de nossas capacidades cognitivas (Workman \& Reader, 2004). Assim como as estruturas físicas, as capacidades cognitivas e emocionais evoluíram para resolver problemas de significado adaptativo (Brüne, 2002). O que a Psicologia evolucionista acrescenta é a compreensão funcional de que as emoções existem para nos levar a desejar as coisas que levaram nossos ancestrais a serem bem sucedidos em termos de aptidão abrangente no Ambiente de Adaptação Evolutiva (AAE). Reagimos com alegria quando a nossa busca de alvos biossociais significativos é bem sucedida e com raiva ou tristeza, quando é frustrada. Evitamos as coisas que ameaçaram a aptidão abrangente ${ }^{2}$ em seu AAE.

O caráter funcional do pensamento evolucionista levanos a descrever as emoções como resultado de seleção e a atribuir-lhes um valor adaptativo. Não será necessário um grande esforço para conceber a função do medo, do nojo e de outras emoções. É preciso, no entanto, no caso específico do ser humano, fazer uma ressalva importante. Nossa espécie é recente; alterações dramáticas da nossa anatomia e do nosso

2 Aptidão abrangente refere-se à seleção no nível do gene, sendo a aptidão determinada pela sobrevivência de todos os indivíduos numa população que são portadores desse gene. modo de vida aconteceram depressa, em poucos milhões de anos. E de forma ainda mais dramática, muito recentemente, em poucos milhares de anos, as mudanças culturais foram enormes. De um modo geral, para o conjunto dos seres vivos, a evolução não significa que as transformações ocorram de modo harmonioso e sincronizado. Entre dois momentos de sua evolução, uma espécie pode ter alguns aspectos já transformados enquanto outros estão "atrasados". Por exemplo, a análise funcional das espécies de animais e plantas domesticadas pelo ser humano exige que se procure imaginar seus antigos ambientes de evolução; sem esse recurso, não será possível entender seu comportamento. De forma semelhante, a compreensão das emoções humanas requer a noção de ambiente de evolução antigo, e será natural que se constate que, em alguns casos, elas não se mostrem ajustadas ao modo de vida atual.

\section{Emoção e cognição como funções mentais interativas}

Vale mencionar neste ponto, a hipótese de marcador somático (Damasio, Tranel \& Damasio, 1991) que sustenta que as atividades somáticas implicitamente criam tendências no comportamento humano. Damasio (1996) acredita ser essa noção relevante para a compreensão de processos de raciocínio humano e tomada de decisão. O setor ventromedial do córtex pré-frontal é crítico para essas operações, apesar de a hipótese não se aplicar necessariamente ao córtex pré-frontal como um todo e não ser uma tentativa para unificar as funções do lobo frontal operando com um único mecanismo. A idéia fundamental da hipótese do marcador somático é a de que as respostas a estímulos acontecem em múltiplos níveis de operação, alguns dos quais ocorrem explicitamente (conscientemente) e outros implicitamente (não-conscientemente). A inibição (não deliberada) de uma resposta previamente aprendida ou a tendência na seleção de um comportamento ilustram a ação implícita dos marcadores. Exemplos de ação explícita incluem a consciência que qualifica certas opções de respostas como perigosas ou vantajosas. A hipótese do marcador é uma rejeição da idéia de que o raciocínio e a tomada de decisões sejam propiciados por mecanismos de conexão restritos ao condicionamento ou à cognição no sentido tradicional. A descrição dos casos clínicos que inspiraram a teoria do marcador somático pode elucidar as ligações entre razão e emoção propostas por Damásio (1996). Alguns pacientes por ele estudados, com lesões nos lobos pré-frontais, embora revelassem um bom desempenho em testes de inteligência, memória, aprendizado e cálculos aritméticos, apresentavam uma grande perturbação nos processos de tomada de decisão, associada a mudanças de personalidade e a desajustamentos no contato social. Dentre as características identificadas, destacou-se uma emocionalidade atenuada, que ao invés de favorecer o raciocínio, parecia impedir a sua funcionalidade nas situações cotidianas. Os pacientes percebiam bem a gravidade dos problemas, mas, estranhamente, pareciam não se dar conta daquilo que percebiam, como se soubessem, mas não sentissem. Não obstante seus bons resultados nos testes, na vida real tinham dificuldades surpreendentes de tomar decisões. Damásio concluiu que a aparente frieza de raciocínio parecia impedir a atribuição de valores e perturbar a tomada de decisão e desenvolveu uma teoria sobre o raciocínio e as 
decisões, na qual marcadores emocionais atuam como parte essencial do processo.

Nas relações que se estabelecem entre as pessoas, tomar uma decisão envolve analisar vantagens e desvantagens, ganhos e perdas, nas mais variadas instâncias sociais. O comportamento de decidir sobre algo, parece incluir, de acordo com Damásio, uma atividade cerebral explícita (sob o domínio de estruturas ou mecanismos cognitivos) e outra implícita (sob o domínio de mecanismos emocionais). Por exemplo, quando são usados comportamentos cooperativos ou competitivos, as pessoas ponderam sobre o que vão ganhar e perder e agem, muitas vezes, visando um ganho imediato mesmo que venham a perder a longo prazo. Isto pode ser indicativo da predominância de um mecanismo emocional nessa decisão. As considerações sobre a evolução de padrões altruístas e egoístas, que serão apresentadas a seguir, ilustram o efeito da aplicação da perspectiva evolucionista na compreensão dos processos psicológicos, bem como demonstram a complexidade da ligação entre emoção e cognição.

\section{A mente evolucionista e o comportamento cooperativo}

O fundamento básico da teoria da evolução é a competição entre indivíduos. Dawkins (1976) propõe a controvertida tese do gene egoísta, sugerindo que os organismos não são mais do que veículos para genes imortais. Dentro dessa moldura teórica, o altruísmo aparece como um problema difícil de superar. O próprio Darwin (1859/2005) considerava os insetos sociais, que abrem mão de sua reprodução em favor do crescimento e estabilidade do grupo, como uma dificuldade especial. Até meados do século passado essa questão não parecia resolvida, e deu margem a explicações que hoje se mostram completamente equivocadas, como a seleção de grupo $^{3}$. As respostas vieram apenas em meados do século xx, com Hamilton (1964a,b) e Axelrod e Hamilton (1981) que propuseram os mecanismos de seleção de parentesco ${ }^{4}$

Tabela 2. Custos e benefícios para doadores e recipientes em cinco tipos de interações (Adaptado de Alcock, 2001).

\begin{tabular}{lcc}
\hline \multicolumn{1}{c}{ Tipo de interação } & \multicolumn{2}{c}{ Benefícios (+) e Custos (-) } \\
\cline { 2 - 3 } & Doador & Recipiente \\
\hline Cooperação & + & + \\
Altruísmo recíproco (atrasado) & + & + \\
Altruísmo & - & + \\
Egoísmo & + & - \\
Despeito (vingança) & - & - \\
\hline
\end{tabular}

3 A seleção de grupo propõe que o indivíduo age em benefício do grupo, mesmo que essa ação venha a prejudicá-lo. Esta teoria não se sustenta, do ponto de vista evolutivo, pois um indivíduo que se sacrifica pelo grupo não consegue passar os genes altruístas adiante. Nessas circunstâncias, os indivíduos egoístas, que se beneficiaram dos generosos é que terão sobrevivido e passado seus genes (egoístas) para a próxima geração.

4 A lei de Hamilton (1964a), que explica a seleção de parentesco, estabelece que um indivíduo deve cooperar quando o doador tem uma proporção de genes em comum (parentesco) com o recipiente, que supera a relação custo/benefício do ato altruísta. e altruísmo recíproco. O mecanismo que mais nos interessa e que será discutido aqui é o segundo, porque envolve a cooperação entre indivíduos não aparentados.

Antes de seguir adiante, é importante esclarecer o conceito de comportamento altruísta. Do ponto de vista da teoria evolucionista, um ato altruísta é aquele que promove a aptidão do recipiente às custas do doador. Esta definição é distinta da social, que considera como altruísta a maioria dos atos que beneficiam o recipiente, sem considerar os custos para o doador. Portanto, um ato altruísta do ponto de vista social ou moral pode ser egoísta do ponto de vista evolutivo, e esta distinção deve ser lembrada ao longo do texto.

Alcock (2001) sugere cinco possíveis interações que envolvem custos e benefícios, relativos à aptidão do indivíduo, para doadores e recipientes (vide Tabela 2). Nela se pode notar que, em casos de verdadeiro altruísmo, o recipiente deve ser beneficiado às custas do doador.

O interesse nessa discussão é o altruísmo recíproco, que envolve um ato que beneficia o recipiente, com custos para o doador, mas que, mais tarde, é retribuído. Desta forma, os custos para o doador são compensados pelos benefícios obtidos em uma ocasião futura. Este parece um meio excelente para a ocorrência de trocas, no qual os dois participantes se beneficiam, compensando os custos incorridos. Por que este tipo de troca não é observado em todas as espécies? Como o próprio Hamilton (1964a,b) já ressaltava, algumas condições devem ser cumpridas para que este tipo de troca ocorra:

1. Deve haver uma alta probabilidade de reencontro entre os participantes para que haja possibilidade de retribuir. Isto significa que o altruísmo recíproco só pode ser usado com vantagens por espécies que têm longo tempo de vida e formam grupos estáveis;

2. O reconhecimento individual é obrigatório para que cada indivíduo saiba a quem prestou favores e, portanto, quem deve retornar o favor prestado. Também é importante que seja possível reconhecer os trapaceiros, isto é, que a memória seja suficiente para saber quais os recipientes de doação que não retribuem o favor;

3. A razão "custo para doador/benefício para recipiente" é baixa, isto é, o favor custa pouco a quem o presta e significa muito para quem o recebe. Isto, como veremos depois, torna a retribuição mais provável.

Um modelo desenvolvido por Axelrod e Hamilton (1981) para explicar o altruísmo recíproco é o chamado dilema do prisioneiro. Este modelo supõe situações como a de dois comparsas que cometeram um delito conjuntamente e que, presos, enfrentam o dilema de delatar ou não o outro. Como eles são colocados em salas separadas para o interrogatório, cada um não sabe se o outro irá delatá-lo (trapaça) ou silenciar (cooperação). São quatro as possíveis situações descritas na Tabela 3.

Considerando todas as situações, a melhor estratégia é sempre trapacear, pois para que a cooperação traga benefícios é necessário que o outro jogador coopere, o que é duvidoso. Como o comportamento do outro jogador não pode ser previsto, trapacear é a melhor solução. Se isto é verdade, como a cooperação evoluiu na espécie humana?

Cartwright (2000) lembra que as interações entre dois jogadores, geralmente, são repetidas. Nesses casos a cooperação é mais provável porque, nas ocasiões nas quais 
Tabela 3. O dilema do prisioneiro: conseqüências para o jogador 1.

\begin{tabular}{lll}
\hline \multirow{2}{*}{ Jogador 1 } & \multicolumn{2}{c}{ Jogador 2 } \\
\cline { 2 - 3 } & $\begin{array}{c}\text { Coopera (mantém o } \\
\text { silêncio) }\end{array}$ & \multicolumn{1}{c}{ Trapaceia (delata) } \\
\hline $\begin{array}{l}\text { Coopera (mantém o } \\
\text { silêncio) }\end{array}$ & $\begin{array}{l}\text { Recompensa pela } \\
\text { cooperação mútua (os } \\
\text { dois prisioneiros são } \\
\text { libertados) }\end{array}$ & $\begin{array}{l}\text { Punção máxima } \\
\text { (recebe pena máxima } \\
\text { enquanto que seu } \\
\text { comparsa é libertado) }\end{array}$ \\
Trapaceia (delata) & $\begin{array}{l}\text { Recompensa máxima } \\
\text { (é liberado enquanto } \\
\text { seu comparsa recebe } \\
\text { pena máxima) }\end{array}$ & $\begin{array}{l}\text { Punição pela trapaça } \\
\text { (os dois recebem uma } \\
\text { pena intermediária) }\end{array}$ \\
\hline
\end{tabular}

os jogadores interagem novamente, pode haver retaliação pela falta de cooperação. Nessas circunstâncias, pode se desenvolver uma Estratégia Evolutivamente Estável ${ }^{5}$ com as seguintes regras: (i) cooperar incondicionalmente na primeira vez; (ii) nunca ser o primeiro a trapacear; (iii) em caso de ser trapaceado, retaliar, mas voltar a cooperar caso o parceiro passe a cooperar.

A crítica que se faz a essa estratégia é que ela é extremamente vulnerável a falhas de comunicação. Além do mais, grande parte das interações das quais participamos envolvem muitos jogadores, e não apenas dois. Muitas dessas interações são únicas - interagimos com pessoas que nunca mais iremos encontrar. Entretanto, deve-se notar que as interações únicas com as quais nos deparamos quase que diariamente correspondem a uma novidade muito recente em termos evolutivos, pois o homem ancestral em geral interagia com os membros do próprio grupo. A facilidade e rapidez dos transportes no mundo moderno tornaram este tipo de interação muito freqüente, em associação ao novo modo de vida agrícola e industrial. Porém, nossa mente ainda responde a essas situações do modo ancestral, provinciano. Nessas condições, a possibilidade de ocorrência de trapaça aumenta, pois o controle e a punição dos trapaceiros tornamse mais raros e difíceis.

Gintis, Smith e Bowles (2001) e Milinski, Semmann e Krambeck (2002) sugerem que a sinalização resolve a questão da cooperação no jogo de múltiplos jogadores, também chamado de "tragédia dos comuns"6. Esta sinalização é, na maior parte das vezes, a reputação de um indivíduo que, quando conhecida, traz benefícios nas interações futuras baseadas na reciprocidade. A reputação, no caso, agiria como um sinal honesto da disponibilidade do indivíduo em cooperar, facilitando a cooperação dos parceiros potenciais.

As emoções na base do entendimento da moral, e possíveis explicações evolucionistas das ações humanas para cooperar e para trapacear

Comportamentos chamados de morais, que eram provavelmente freqüentes entre nossos ancestrais, são geralmente acompanhados de sentimentos. Eles são a culpa e o remorso

5 Estratégias Evolutivamente Estáveis ou EEE são um conjunto de regras de comportamento que, uma vez adotado pelos membros de um grupo, dificilmente pode ser superado por uma estratégia alternativa.

6 A tragédia dos comuns é representada pela situação na qual um recurso público de uso comum é superexplorado, como no caso da conservação dos recursos naturais. quando consideramos que tratamos o outro de maneira injusta, a gratidão quando recebemos um favor, a indignação e a compaixão quando vemos algo que consideramos inadequado ou injusto. Cartwright (2000) sugere que as freqüentes interações que envolviam altruísmo recíproco, e que favoreciam os reciprocadores, tenham deixado marcas na mente humana que favorecem os sentimentos morais, tal como sugerido por Ridley (2000). Nesse sentido, nosso cérebro seria sensível às trocas sociais, e favoreceria a cooperação com altruístas e diminuiria aquelas com os trapaceiros ou com aqueles que não cooperam (Barkow \& cols., 1992; Gaulin \& MacBurney, 2001). São nossas emoções, e não a razão, a garantia de nossos compromissos.

Por exemplo, um soldado que se expõe ao fogo inimigo para socorrer um companheiro ferido, age irracionalmente. $\mathrm{O}$ mais lógico a fazer seria fugir, abandonando o companheiro e salvando a si próprio. Porém, seu senso de dever para com o companheiro, a questão da honra, é que o leva a arriscar a vida para salvar a do outro. As trocas sociais ao longo de nossa evolução levaram ao desenvolvimento de sentimentos relativos ao nosso comportamento e ao de outros, que chamamos de senso de justiça.

Pode-se concluir, então, que a espécie humana é altruísta? Fazemos o bem sem olhar a quem? Na realidade não. Cartwright (2000) e Ridley (2000) sugerem que a moralidade é um meio através do qual indivíduos tentam induzir o comportamento moral nos outros, em seu próprio interesse. Recursos comuns só podem ser mantidos se a maioria coopera. Portanto, os trapaceiros (free-riders), aqueles que usam o recurso comum sem pagar por ele ou contribuir para sua manutenção, prejudicam a todos. A vigilância e a punição dos transgressores beneficiam a todos, mas também beneficiam particularmente o indivíduo que coopera. A moralidade, portanto, é um comportamento que serve a interesses egoístas, na medida em que aumenta a aptidão do cooperador (Wright, 1994/1996).

\section{Considerações Finais}

O que nos faz ser o que somos? Ou melhor, como a arquitetura neural possibilita determinados comportamentos? Esses são os questionamentos subjacentes a este trabalho, que procurou destacar e interligar dois aspectos:

a) A compreensão evolucionista da mente humana, em termos de sua arquitetura, resultante da seleção natural, que se apóia em dois pilares: o da plasticidade e o da especificidade dos sistemas neurais. Aparentemente opostos, devem ser entendidos como complementares e desempenhando funções distintas em variados momentos do desenvolvimento ontogenético e filogenético. Um possibilita a existência do outro. A plasticidade é fundamental para que a adaptação aos diferentes ambientes seja possível. A adaptação favorece a repetição de determinadas ações e isso vai tornando os sistemas neurais específicos. Plasticidade e especificidade podem ser entendidas como aspectos de um mesmo processo integrado, moldado pela evolução. De maneira análoga, as discussões recentes têm mostrado que os conceitos de especializações cognitivas não são incompatíveis com as idéias de fluidez cognitiva ou de mecanismos gerais de integração. A constatação da existência de especializações mentais 
adaptativas permitiu um aprimoramento da compreensão dos processos cognitivos humanos, corrigidos os exageros que levaram à concepção de uma mente modular extrema, formada por especializações encapsuladas. Embora ainda estejamos distantes de uma superação dessas questões, as propostas teóricas devem ser avaliadas pelo seu valor na geração de pesquisas.

b) A compreensão evolucionista da mente humana em termos de seu funcionamento assenta-se, também, em dois pilares: a razão e a emoção. A inclusão dos aspectos emocionais e afetivos nos processos cognitivos também parece representar uma tendência contemporânea heurística. Novamente, razão e emoção devem ser entendidas como complementares, desempenhando funções distintas em variados momentos do desenvolvimento filogenético e ontogenético.

O que se procurou demonstrar é que tomar decisões, comportar-se de uma determinada maneira, fazer escolhas, agir como free-rider ou seguir padrões morais do grupo dependem tanto de mecanismos racionais quanto emocionais. Ingênuo pensar os indivíduos da espécie humana pautando-se em avaliações de custo-benefício de suas condutas, prescindindo das emoções. Estas são balizadoras fundamentais das ações individuais. Certamente que a integração dos aspectos emocionais e cognitivos não se dá de uma maneira muito simples, nem é tão óbvia. Por muito tempo, como já foi mencionado, as emoções não foram consideradas como tendo um papel importante nas instâncias cognitivas do comportamento. É bastante recente considerar que as avaliações e tomadas de decisões da espécie humana parecem depender de mecanismos corticais e também de mecanismos subcorticais, muitos deles ocorrendo em níveis inconscientes. A forma final da arquitetura mental humana é resultado de intrincadas interações que estão a demandar muitas investigações empíricas para que hipóteses explicativas sejam aventadas e testadas.

O comportamento cooperativo, que em última instância visa preservar o próprio interesse, serviu para ilustrar as suposições que nortearam o presente trabalho. A partir da concepção de um comportamento cooperativo pode-se pensar como uma arquitetura mental vai se especializando, e como essa especialização depende de avaliações realizadas em dimensões sociais, culturais, afetivas, emocionais e biológicas.

\section{Referências}

Alcock, J. (2001). Animal Behavior. Sunderland: Sinauer.

Axelrod, R. \& Hamilton, W. D. (1981). The evolution of cooperation. Science, 211(4489), 1390-1396.

Barkow, J. H.; Cosmides, L. \& Tooby, J. (Orgs.) (1992). The adapted mind. Oxford: Oxford University Press.

Brüne, M. (2002). Toward an integration of interpersonal and biological processes: Evolutionary psychiatry as an empirically testable framework for psychiatric research. Psychiatry, 65, 48-57.

Cartwright, J. (2000). Evolution and Human Behavior: Darwinian Perspectives on Human Nature. Cambridge: MIT Press.

Cosmides, L. \& Tooby, J.(1999). Evolutionary psychology. MIT Encyclopedia of Cognitive Science. Cambridge: MIT Press.

Cosmides, L. \& Tooby, J. (2000). Evolutionary psychology and the emotions. Em M. Lewis \& J. M. Haviland-Jones (Orgs.),
Handbook of Emotions (2 ${ }^{\text {a }}$ ed., pp. 91-115). New York: Guilford.

Damasio, A. R. (1996). The somatic marker hypothesis and the possible functions of the prefrontal cortex. Philosophical Transactions of the Royal Society of London, 351, 14131420 .

Damasio, A.; Tranel, D. \& Damasio, H. C. (1991). Somatic markers and the guidance of behavior: Theory and preliminary testing. Em H.S. Levin; H.M. Eisenberg \& A. L. Benton (Orgs.), Frontal lobe function and dysfunction (pp. 217-229). New York: Oxford University Press.

Damásio, A. (2000). Em busca de Espinosa - prazer e dor na ciência dos sentimentos. São Paulo: Companhia das Letras.

Darwin, C. (2005). The origin of species. London: Murray. (Trabalho original publicado em 1859)

Darwin, C. (1965). The expression of the emotions in man and animals. Chicago: University of Chicago Press. (Trabalho original publicado em 1872)

Dawkins, R. (1976). The Selfish Gene. Oxford: Oxford University Press.

Evans, D. \& Zarate, O. (1999). Introducing evolutionary psychology. Cambridge: Icon Books.

Fodor, J. (1983). The modularity of mind. Cambridge: The MIT/ Bradford Press.

Gardner, H. (1985). The mind's new science: a history of the cognitive revolution. New York: Basic Books.

Gaulin, S. J. C. \& MacBurney, D. H. (2001). Psychology: an evolutionary approach. New Jersey: Prentice Hall.

Gintis, H.; Smith, E. A. \& Bowles, S. (2001). Costly signaling and cooperation. Journal of Theoretical Biology, 213, 103-119.

Hamilton, W. D. (1964a). The evolution of social behavior I. Journal of Theoretical Biology, 7, 1-16

Hamilton, W. D. (1964b). The evolution of social behavior II. Journal of Theoretical Biology, 7, 17-52.

Karmiloff-Smith, A. (1995). Beyond modularity: a developmental perspective on cognitive science. Cambridge: The MIT Press.

Karmiloff-Smith, A. (2000). The connectionist infant: would Piaget turn in his grave? Em A. Slater \& D. Muir (Orgs.), The Blackwell reader in developmental psychology (pp. 43-52). Oxford: Blackwell.

Keller, H. (2000). Human parent-child relationships from an evolutionary perspective. American Behavior Scientist, 43(6), 957-969.

LeDoux, J. (1998). O cérebro emocional: os misteriosos alicerces da vida emocional. (T. B. dos Santos, Trad.). Rio de Janeiro: Objetiva. (Trabalho original publicado em 1996)

LeDoux, J. E. (1994). Emotion, memory and the brain. Scientific American, 270, 32-39.

LeDoux, J. (2002). Synaptic Self: how our brains become who we are. New York: Penguin Books.

Milinski, M.; Semmann, D. \& Krambeck, H. J. (2002). Reputation helps solve the 'tragedy of the commons'. Nature, 415(6870), 424-426.

Mithen, S. (1998). A pré-história da mente: uma busca das origens da arte, da religião e da ciência. (L. C. B. de Oliveira, Trad.) São Paulo: Editora da UNESP. (Originalmente publicado em 1996).

Penna, A. G. (1986). Cognitivismo, consciência e comportamento político. São Paulo: Vértice. 
Ridley, M. (2000). As origens da virtude: um estudo sociobiológico da solidariedade. (B. Vargas, Trad.) Rio de Janeiro: Editora Record. (Publicado originalmente em 1996)

Rode, C. \& Wang, X. (2000). Risk-sensitive decision making examined within an evolutionary framework. American Behavior Scientist, 43(6), 926-939.

Rodrigues, M. M. P. \& Otta, E. (2002). Desenvolvimento sócioafetivo de bebês: alguns fundamentos evolutivos. Em S. A. da S. Leite (Org.), Cultura, Cognição e Afetividade: a sociedade em movimento (pp. 69-84). São Paulo: Casa do Psicólogo.

Seidl de Moura, M. L. (2005). Dentro e fora da caixa preta: a mente sob um olhar evolucionista. Psicologia: Teoria e Pesquisa, 21(2), 141-147.
Workman, L. \& Reader, W. (2004). Evolutionary psychology: An introduction. Cambridge: Cambridge University Press.

Wright, R. (1996). O animal moral. Porque somos como somos: a nova ciência da psicologia evolucionista (L. Wyler, Trad.). Rio de Janeiro: Editora Campus. (Publicado originalmente em 1994).

\section{CONGRESSO NACIONAL DE ETOLOGIA}

Data: 02 a 03 de Junho de 2006

Local: Universidade de Coimbra - Portugal

\section{Organização}

Sociedade Portuguesa de Etologia

Informações e inscrições

http://www.uc.pt/etologia/

e-mail: etologia@ci.uc.pt 